\title{
Award-winning papers in 2013
}

Papers published in Bridge Engineering are eligible for awards from the Institution of Civil Engineers. Papers from any of the ICE journals can be nominated for several awards. In addition, each journal has awards dedicated to their specific subject area.

On Friday 17 October 2014, ICE president Geoff French presented an award to the following paper published in Bridge Engineering in 2013. The editorial panel nominated their best papers and an awards committee chaired by Quentin Leiper allocated the awards.

\section{Baker Medal}

The Baker Medal, awarded to development or investigation in either bridges, dams, tunnels, soil mechanics, foundations, transport, research or materials, was awarded to Reis et al. (2013).

\begin{abstract}
The Zambezi River Bridge between Caia and Chimuara is one of the longest and most important bridges built in Africa in recent years. The $2376 \mathrm{~m}$ long bridge provides a vital connection between the south and north of Mozambique, substituting the ferry connection to the national road 1 that has existed for almost 50 years. The topography of the site, the deep foundations, the size and significance of the river channel and the environmental sensitivities shaped almost every aspect of the bridge design and construction presented here, including the route selection, the structural forms and the construction methods.
\end{abstract}

\section{John Henry Garood King Prize}

The John Henry Garood King Prize, awarded to the best paper on tunnels, soil mechanics or bridges, was awarded to Barbosa et al. (2013).

\section{Abstract}

A new moveable footbridge was recently built at the entrance of Marina Atlântico in the city of Viana do Castelo, Portugal. This paper presents a brief description of the global solution, with a special focus on the characterisation of the construction methods adopted. Particular consideration is given to the construction of the pivot pylon and the steel structure, showing how all the bridge components work together to ensure a safe working relationship with the marina, the river and users of the continuous bicycling and pedestrian pathway running across the closed bridge. The mechanical, hydraulic, electrical and navigational light systems play fundamental roles, especially during bridge opening and closing operations. Moreover, as this light footbridge is susceptible to vibrations due to human traffic, the paper also describes the dynamic tests performed during and

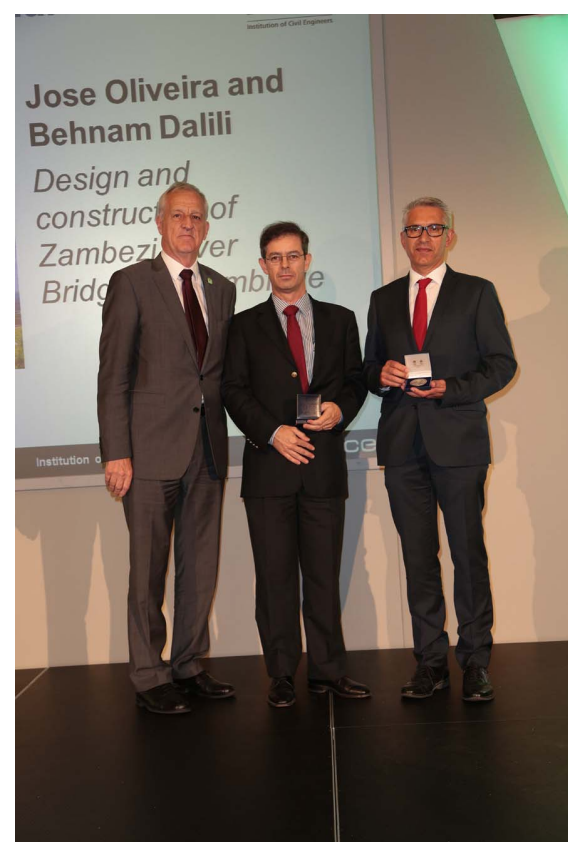

THE ICE President, Geoff French, awarding José Oliveira Pedro and Behnam Dalili the Baker Award

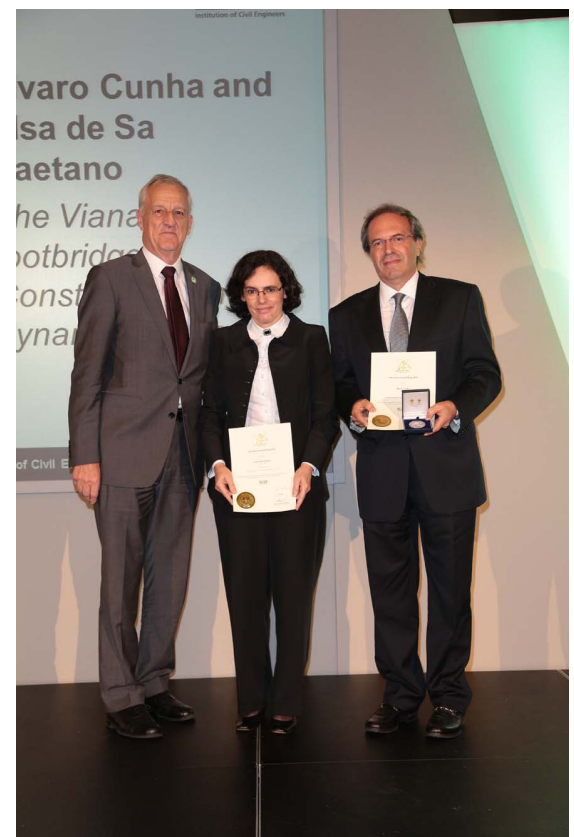

Elsa Caetano and Álvaro Cunha receiving the John Henry Garood King Prize from ICE President Geoff French 
Proceedings of the Institution of Civil Engineers - Bridge Engineering 166(4): 273-290, http://dx.doi.org/10.1680/ bren.10.00048.

Reis AJ, Oliveira Pedro JJ and Dalili B (2013) Design and construction of Zambezi River Bridge, Mozambique. Proceedings of the Institution of Civil Engineers - Bridge Engineering 166(2): 104-125, http://dx.doi.org/10.1680/ bren.11.00028.

\section{REFERENCES}

Barbosa R, Magalhães F, Caetano E and Cunha Á (2013) The

Viana footbridge: construction and dynamic monitoring. 